\title{
Lysimachia (Myrsinaceae) in New South Wales
}

\author{
P.G. Kodela \\ National Herbarium of New South Wales, Botanic Gardens Trust, Mrs Macquaries Road, \\ Sydney NSW 2000, Australia
}

\begin{abstract}
This paper describes and provides a key to Lysimachia taxa occurring in New South Wales: L. fortunei, L. japonica and L. vulgaris var. davurica.
\end{abstract}

\section{Introduction}

Lysimachia was previously placed in the family Primulaceae, but a recent phylogenetic study analysing molecular and morphological data of primuloid families supports the transfer of the genus to Myrsinaceae (Källersjö et al. 2004). In addition to the synopsis of diagnostic morphological characters of the family provided by Källersjö et al. (2004), many Lysimachia species have schizogeneous secretory cavities that appear as lines or dots on vegetative and reproductive parts, which according to Anderberg and Ståhl (1995) are characteristic of Myrsinaceae.

Lysimachia is a cosmopolitan genus more common in the Northern Hemisphere. There are about 180 or possibly up to 250 species of Lysimachia worldwide. Some species have medical and culinary uses, particularly in Asia.

When the treatment for Lysimachia was first published in the Flora of New South Wales (Makinson 1990), two species were known to occur in New South Wales. Since then there have been changes to the known distribution of L. japonica (one new and one historic record from South Coast) and L. vulgaris var. davurica (extensions of range to South Coast and Southern Tablelands), as well as an additional species, L. fortunei, recorded for the State. In these three perennial species, the flowers are 5-merous with a deeply dissected, \pm campanulate, persistent calyx and a deeply dissected, campanulate to rotate corolla.

This paper provides an updated brief treatment of the Lysimachia taxa occurring in New South Wales and was undertaken in order to revise the NSW FloraOnLine (http://plantnet.rbgsyd.nsw.gov.au/floraonline.htm). There is further scope for detailed taxonomic assessment of the genus in Australia. 


\section{Key to Lysimachia taxa in New South Wales}

1 Stems \pm prostrate, to $18 \mathrm{~cm}$ long, pilose with septate hairs; leaves ovate or broadly ovate to \pm spathulate, to $2.5 \mathrm{~cm}$ long; flowers solitary in leaf axils; pedicels without basal bract; corolla close to or barely exceeding length of the calyx

1 L. japonica

$1^{\star}$ Stems erect, to $2 \mathrm{~m}$ high, minutely glandular-hairy or \pm glabrous; leaves elliptic to narrowly elliptic, lanceolate or oblanceolate, mostly 3-9 cm long; flowers in panicles or racemes; pedicels with basal bract; corolla distinctly exceeding calyx.

2 Leaves mostly opposite or in whorls, minutely glandular-hairy particularly along veins (on both surfaces or mainly on lower surface) and margin; pedicels 5-12 $\mathrm{mm}$ long, slender, distinctly longer than bract; calyx apices acuminate, margins glandular streaked; corolla yellow, 6-9 $\mathrm{mm}$ long 2 Lysimachia vulgaris var. davurica

$2^{\star}$ Leaves mostly alternate, glabrous; pedicels 1-5 mm long, stout, as long as or shorter than bract; calyx apices obtuse, margins membranous; corolla white, to $5.5 \mathrm{~mm}$ long

3 Lysimachia fortunei

1. Lysimachia japonica Thunb., Fl. Jap.: 83 (1784)

Trailing, stoloniferous herb; stems \pm prostrate, rooting at lower nodes, often ascending towards ends, to $18 \mathrm{~cm}$ long or possibly longer, with \pm retrorse, often slightly crisped, hyaline, septate hairs (to c. $0.5 \mathrm{~mm}$ long) and scattered minute reddish glandularpapillae. Leaves mostly opposite, occasionally subopposite or alternate on some stems; lamina ovate or broadly ovate to \pm spathulate, mostly $0.8-1.7 \mathrm{~cm}$ long and 5-15 mm wide, with scattered minute reddish glandular dots (glandular punctate) and hyaline, septate hairs; petiole $2-10 \mathrm{~mm}$ long, narrowly winged. Flowers solitary, axillary, usually 5-8 mm diam.; pedicel 1.5-5 mm long (reported to $10 \mathrm{~mm}$ long in overseas treatments), without a bract; sepals 4-7 mm long, lanceolate with acuminate to \pm subulate apex and scattered septate hairs, glandular-spotted; petals not or scarcely exceeding the sepals, 3.5-5.5 mm long, yellow, apex acute or obtuse; filaments glabrous. Capsule globose or subglobose, 2-3(-4) mm diam., much shorter than persistent calyx, usually minutely pilose at apex, longitudinally dehiscing from apex by 5 valves, many-seeded. Flowering mainly November - January; also recorded flowering in April and possibly later. Fig. 1a-c. Common name: Creeping Loosestrife.

Habitat: moist situations, in and on margins of rainforest, on stream banks and in swamps, including swampy shallow drainage lines on flats.

Distribution: mainly north from the Williams River (Barrington area), with an historic record from Tilba Tilba (1881) and a more recent record from near Bega (1996); also Victoria where reported to be of uncertain status (see Walsh 1996) and widespread from Japan and Taiwan west to the Himalaya region, India and Sri Lanka and south through Indochina to Indonesia and Papua New Guinea. Occurrences in Queensland and perhaps eastern Victoria would not be improbable.

Conservation status: not listed as threatened or endangered in New South Wales where it is locally frequent to rare in various moist habitats. 
Selected specimens: New South Wales: North Coast: near Williams River, 1802-5, R. Brown (MEL237010!, NSW155424!); Wiangarie State Forest, 27 Dec 1979, R.G. Coveny 10560 \& P.D. Hind (NSW!), southern end of Gloucester Bucketts, 1 Jan 1994, R.G. Coveny 16710 (BRI, CANB, K, MEL, MO, NSW!), Bentley, Richmond River, 1893, A.H. Edwards (MEL1517684!); above Shannon Creek, c. $30 \mathrm{~km}$ S of Grafton, 10 Apr 2002, J. \& P. Edwards (NSW498015!), upper Bellinger River, Bishops Creek, 30 Nov 1993, P. Gilmour 7512 (CANB, MEL, NSW!); Tooloom Range, Dec 1907, J.H. Maiden (NSW155422!); South Coast: Tilba Tilba, Nov 1881, M. Bate 207 (MEL!); Jellat Flat, 5 km SE of Bega, 26 Nov 1996, J. Miles (NSW433736); Northern Tablelands: N of Mooraback Rest Area, Werrikimbe National Park, 5 Dec 1987, J.R. Hosking (NSW213496!, TARCH).

2. Lysimachia vulgaris var. davurica (Ledeb.) Knuth, Pflanzenr. IV 237 (Heft 22): 304 (1905)

\section{L. davurica Ledeb., Mém. Acad. Imp. Sci. St Pétersbourg Hist. Acad. 5: 523 (1812)}

Rhizomatous herb; aerial stems erect, simple or weakly branched, to $1.5(-2) \mathrm{m}$ high, with minute, erect, reddish brown-tipped glandular hairs (to $0.1 \mathrm{~mm}$ long or slightly longer) and some times with occasional longer septate hairs intermixed, becoming glabrous on lower stem. Leaves mostly opposite or in whorls of 3 or 4, elliptic to narrowly elliptic, lanceolate or oblanceolate, mostly 4-9 cm long and 10-22 (-32) $\mathrm{mm}$ wide (leaves becoming smaller towards stem apex), often long and narrow (to 10.5 $\mathrm{cm}$ long, 7-8 mm wide) on young plants, discolorous, green, paler beneath, minutely glandular-hairy, dotted with orange to blackish glands (glandular punctate), sessile or with petiole to $3 \mathrm{~mm}$ long. Panicles terminal and upper-axillary, many-flowered. Flowers 9-15 mm diam.; pedicel mostly 5-12 $\mathrm{mm}$ long, with a distinctly shorter basal bract 2-6 $\mathrm{mm}$ long; sepals 3-4 $\mathrm{mm}$ long, lanceolate-ovate with an acuminate apex and distinct orange to blackish (on drying) glandular line on the outer surface near the margins, ciliolate with gland-tipped hairs; petals clearly exceeding the sepals, 6-9 $\mathrm{mm}$ long, bright yellow, often with minute orange to reddish glandular lines or dots, apex broadly acute to obtuse; filaments with minute glandular hairs. Capsule globose or subglobose, $2-4 \mathrm{~mm}$ diam., longer than persistent calyx when mature, with minute gland-tipped hairs at apex, longitudinally dehiscing from apex by (4-)5 valves, manyseeded. Flowering December - March. Aerial stems die back after flowering and fruiting. Fig. 1d-f. Common name: Yellow Loosestrife.

Habitat: moist situations, including peatland swamps, stream banks and lagoons. Grows in damp soils to saturated peat, in sedgeland and wet heath communities, associated with Phragmites australis, Carex spp., Juncus spp., Bolboschoenus fluviatilis, Lycopus australis, Lythrum salicaria, Leptospermum spp. and Melaleuca ericifolia.

Distribution: rare in Australia; recorded in several wetlands in New South Wales, including Wingecarribee Swamp between Robertson and Moss Vale, a swamp/pond system in the Lower Boro - Braidwood area, and a lagoon near Bega. These populations are far disjunct from the main natural range of this taxon in NE Asia where it occurs from Japan west to Mongolia and eastern Russia. Its occurrence in Australia may provide evidence supporting long-distance dispersal; in this case the agency is likely to have been migratory waterbirds, such as Latham's (Japanese) Snipe, which visit Australian wetlands in the summer. Both var. davurica and var. vulgaris have been recorded in Victoria with uncertain status (see Walsh 1996). 


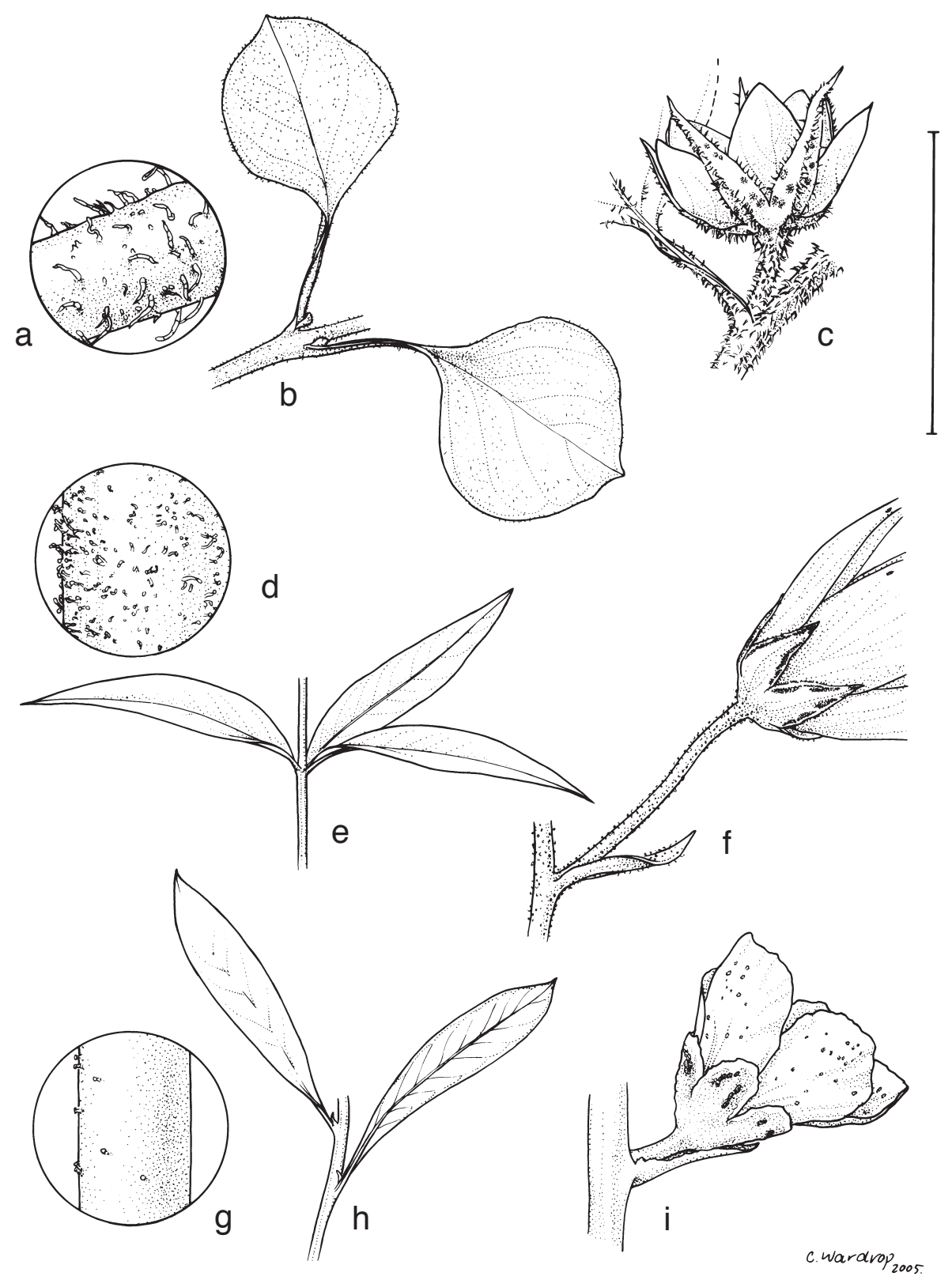

Fig. 1. Lysimachia japonica. a, b, part of stem; c, flower. L. vulgaris var. davurica. d, e, part of stem; f, flower. L. fortunei. g, h, part of stem; i, flower. a-c, J. \& P. Edwards (NSW498015); d-f, J. Miles (NSW615689); g-i, L.M. Copeland 3557, I.R. Telford \& J. Hodgon (NSW).

Scale bar $=0.24 \mathrm{~cm}(\mathrm{~g}), 0.3 \mathrm{~cm}(\mathrm{a}, \mathrm{d}), 0.75 \mathrm{~cm}(\mathrm{i}), 1 \mathrm{~cm}(\mathrm{c}), 2 \mathrm{~cm}(\mathrm{~b}), 6 \mathrm{~cm}(\mathrm{f}, \mathrm{h})$ or $8 \mathrm{~cm}(\mathrm{e})$. 
Conservation status: listed as Endangered under Schedule 1 of the New South Wales Threatened Species Conservation Act 1995 and is not located in any protected reserves. The largest population in New South Wales is under threat from major disturbance of its wetland habitat since most of the Wingecarribee Swamp peatland collapsed and fragmented in August 1998.

Selected specimens: [precise localities withheld for conservation purposes] New South Wales: South Coast: SE of Bega, 18 Dec 2002, J. Miles (NSW615689!); ibid. 21 Feb 2003 (NSW702297!); Central Tablelands: Wingecarribee Swamp, 26 Feb 1969, R.G. Coveny 906 (CANB, MEL, NSW!), 9 Feb 1988, P.G. Kodela (NSW254143!, UNSW!), 27 Feb 1997, P.G. Kodela (CANB!, K!, MEL!, MO!, NSW425850!, PE!, UNSW!), 28 Mar 2001, P.G. Kodela 574 et al. (CANB!, MEL!, MO!, NSW!), 1 Jun 2001, P.G. Kodela 600a (NSW!); Southern Tablelands: Lower Boro - Braidwood area, 19 Feb 2001, R.O. Makinson 1787 (CANB).

Notes: A possible taxonomic synonym is L. muelleri N.P.Balakr., the replacement name for L. salicifolia Benth. nom. illeg. (Walsh 1996). Investigations by Bob Makinson (pers. comm.) indicate likely synonymy, which has implications for the status of L. vulgaris var. davurica as native based on historic specimens from Victoria labelled as L. salicifolia.

Lysimachia vulgaris L. var. vulgaris and var. davurica are some times treated as separate species (e.g. Hu \& Kelso 1996). The present paper maintains the variety level, with a molecular phylogenetic study finding these taxa to be very close (Hao et al. 2004) and there being strong morphological similarities (pers. obs.).

Lysimachia vulgaris var. vulgaris is native mainly to Europe and is most readily distinguished from var. davurica by having conspicuous, long, septate hairs on the stems, leaves and other parts (pers. obs.). In var. davurica there may be occasional long septate hairs amongst predominantly minute glandular hairs. The leaves may also be broader in var. vulgaris, to $50 \mathrm{~mm}$ wide. There are occasional records of $L$. vulgaris (variety uncertain) from New Zealand and the species is treated as naturalised there. In parts of North America L. vulgaris is a problem weed of wetlands that was probably introduced from Eurasia as an ornamental.

In Chinese folk medicine flavanol glycosides have been extracted from Lysimachia vulgaris var. davurica for treatment of high blood pressure.

3. Lysimachia fortunei Maxim., Bull. Acad. Imp. Sci. Saint-Pétersbourg 12: 68 (1868)

Rhizomatous herb; aerial stems erect (to decumbent), simple or some times branching near apex, reddish, to c. $70 \mathrm{~cm}$ high, with sparse, minute, gland-tipped hairs, appearing \pm glabrous. Leaves mostly alternate, narrowly elliptic or oblanceolate, mostly 3-6.5 cm long and 6-12 $\mathrm{mm}$ wide, glabrous, dotted with minute reddish glands (glandular punctate), \pm sessile. Racemes terminal, many-flowered, to $15 \mathrm{~cm}$ long. Flowers 5-7 mm diam.; pedicel mostly 1-2 $\mathrm{mm}$ long (occasionally to $5 \mathrm{~mm}$ long in basal flowers), with a \pm equally long or longer basal bract 2-4(-5) $\mathrm{mm}$ long; sepals 1.5-2.5 mm long, ovate-elliptic with obtuse apex, glandular-dotted, margins whitishmembranous; petals exceeding the sepals, to $5.5 \mathrm{~mm}$ long, white, often with minute purplish glandular dots and lines, apex rounded; filaments with minute glandular hairs. Fruits not seen. Flowering around February. Fig. 1g-i. Common name (Japan): Swamp Tiger Tail. 
According to Iwatsuki et al. (1993) and Hu and Kelso (1996) the stems can reach $80 \mathrm{~cm}$ high, the leaves can also be lanceolate and to $11 \mathrm{~cm}$ long and $25 \mathrm{~mm}$ wide, the racemes to $20 \mathrm{~cm}$ long and the capsule is globose, $2-2.5 \mathrm{~mm}$ diam., glabrous, dehiscing by valves and many-seeded.

Habitat: moist situations; recorded in New South Wales from a broad gully swamp, growing in peaty loam over basalt, on stream bank and flat, in wetland herbfield with Carex, Geum and Juncus.

Distribution: recorded in Australia only from a swamp in Werrikimbe National Park where it occurs possibly as a result of long distance dispersal by a wetland bird; main natural distribution is in E Asia from China to Japan.

Specimens examined: [precise locality withheld for conservation purposes] New South Wales: Northern Tablelands: Werrikimbe National Park, 13 Feb 2003, L.M. Copeland 3557, I.R. Telford \& J. Hodgon (BRI, CANB, MEL, NE, NSW!, TARCH) \& L.M. Copeland 3566, I.R. Telford \& J. Hodgon (CANB, MEL, NE, NSW!).

Conservation status: rare in Australia, being only recorded from one wetland which is protected in Werrikimbee National Park; status requires further investigation, but L. fortunei is likely to be a 'natural adventive' or 'distance-dispersed native' based on the similar distribution patterns of the other species.

Note: in addition to the more distinct differences in leaf arrangement and inflorescence features (including flower colour), L. fortunei can be distinguished from L. vulgaris var. davurica by the indumentum. In $L$. fortunei the stems appear \pm glabrous with only a few scattered minute hairs while in L. vulgaris var. davurica the minute indumentum is usually moderately dense, at least in the upper parts, as seen with a 10x lens.

\section{Conclusion}

Three Lysimachia taxa are currently known to occur in New South Wales: L. fortunei, L. japonica and L. vulgaris var. davurica. In Australia they are also known from Victoria, along with the commonly cultivated species L. nummularia L. which has been recorded as naturalised.

Because Lysimachia is not widespread or common in Australia and some species are sold for cultivation as ornamentals it has often been assumed that records in the wild represent naturalised escapes in this part of the world. For example, Lysimachia vulgaris var. davurica in Wingecarribee Swamp attracted great debate in 1997 at a mining warden's inquiry on peat mining as to whether it was a rare native or introduced weed growing in the wetland. The presence of this taxon and L. fortunei in particular, in New South Wales, could well provide examples of chance distributions resulting from long distance dispersal, which is not uncommon for cosmopolitan wetland plants. There is no obvious garden escape pattern for the genus in New South Wales and some of the populations are in remote localities. The question of how long some of the populations have been in Australia remains unanswered. Palynological and macrofossil analyses of peat or sediments where Lysimachia grows might be ways of investigating pre-European occurrence. From what is known about the distribution of the genus and the history of specimen records, Lysimachia is likely to be an elusive cosmopolitan in Australia. It is quite possible that new localities for Lysimachia will be found in Australia in the future. 


\section{Acknowledgments}

I am grateful to Bob Makinson, Peter Wilson and Elizabeth Brown for constructive comments on the manuscript. I thank Catherine Wardrop for her skilful illustration. MEL kindly allowed access to specimens.

\section{References}

Anderberg AA \& Ståhl B (1995) Phylogenetic interrelationships in the order Primulales, with special emphasis on the family circumscriptions. Canadian Journal of Botany 73: 1699-1730.

Iwatsuki K, Yamazaki T, Boufford DE \& Ohba H (eds) (1993) Flora of Japan, vol. IIIa. (Kodansha: Tokyo)

Källersjö M, Bergqvist G \& Anderberg AA (2000) Generic realignment in primuloid families of the Ericales s.l.: a phylogenetic analysis based on DNA sequences from three chloroplast genes and morphology. American Journal of Botany 87: 1325-1341.

Makinson RO (1990) Primulaceae. Pp. 504-506 in Harden GJ (ed.) Flora of New South Wales, vol. 1. (New South Wales University Press: Kensington)

Walsh NG (1996) Primulaceae. Pp. 517-522 in Walsh NG \& Entwisle TJ (eds) Flora of Victoria, vol. 3. (Inkata Press: Melbourne)

Hao G, Yuan Y-M, Hu C-M, Ge X-J \& Zhao N-X (2004) Molecular phylogeny of Lysimachia (Myrsinaceae) based on chloroplast trnL-F and nuclear ribosomal ITS sequences. Molecular Phylogenetics and Evolution 31: 323-339.

Hu C-M \& Kelso S (1996) Primulaceae. Pp. 39-189 in Wu Z-Y \& Raven PH (eds) Flora of China, vol. 15. (Science Press: Beijing \& Missouri Botanical Garden: St Louis)

Manuscript received 10 October 2005, accepted 7 February 2006 